\title{
THE EFFECTS ON THE CARDIOVASCULAR SYSTEM OF FLUIDS ADMINISTERED INTRAVENOUSLY IN MAN. II. THE DYNAMICS OF THE CIRCULATION ${ }^{1}$
}

\author{
By MARK D. ALTSCHULE AND D. ROURKE GILLIGAN \\ (From the Surgical and Medical Wards and the Medical Research Department of the Beth \\ Israel Hospital, and the Department of Medicine, Harvard Medical School, Boston)
}

(Received for publication February 15, 1938)

Earlier work from this laboratory (1) has shown that appreciable increases in blood volume occur in man following the injection intravenously of isotonic or hypertonic solutions of crystalloids in volumes of 500 to $1500 \mathrm{cc}$. It has been known for many years from studies in polycythemia vera $(2,3,4,5,6,7)$ that an abnormally large volume of circulating blood in itself causes no significant deviation from the normal in cardiovascular function. Studies of the effects on the cardiovascular dynamics of a rapid increase in blood volume, such as occurs as a result of the administration of large amounts of fluids intravenously are, however, fragmentary. In a few experiments Cohnheim and Lichtheim (8), as long ago as 1877 , noted a rise in both venous and arterial blood pressures in anesthetized dogs as a result of massive intravenous infusions of physiological saline solution. Subsequently, other authors $(9,10,11$, $12,13)$ confirmed these findings. Meek and Eyster (11), Gollwitzer-Meier (12) and Onozaki (14) reported striking increases in the cardiac output of anesthetized animals following the rapid injection intravenously of large volumes of fluid. Observations in man are limited chiefly to studies of the pulse rate, and venous and arterial blood pressures $(15,16,17,18,19)$. In the present work the effect of the intravenous administration of crystalloid solutions on the more important measurable cardiovascular functions in man have been studied.

\section{MATERIAL AND METHODS}

Thirty-five observations were made on 34 subjects aged 17 to 71 years; twenty-six were males and eight females. Many of the patients studied were surgical cases who had had appendectomies, herniorrhaphies, or pelvic repairs; in these cases intravenous fluids were administered 3 to 6 hours postoperatively. Several of the subjects

1 Presented in abstract form at the May 1937 meeting of the American Society for Clinical Investigation. were young convalescent male patients from the medical wards; these cases were essentially normal and agreed to receive intravenous fluid for the purposes of study. One patient was studied while receiving hypertonic saline in the treatment of peripheral vascular disease; studies were made in another patient who suffered from angina pectoris and was receiving fluids intravenously as an attempted therapeutic measure (20). There were no evidences of cardiac decompensation, hypertension, or of marked dehydration in any of the patients on whom observations are reported. The results obtained in the surgical patients and in the unoperated group were the same; all studies, therefore, are treated as one group.

The minute volume output of the heart was measured by the method of Starr and Gamble (21). Studies of the cardiac output before and during the intravenous injections were made with the patient in the postabsorptive state and the semirecumbent position. The respiratory minute volume, tidal air, and basal metabolic rate were estimated in those patients on whom measurements of the cardiac output were made. The velocity of blood flow was estimated from the arm to tongue circulation time, according to the method of Winternitz, Deutsch and Brüll (22). The venous pressure was measured by the direct method of Moritz and von Tabora (23). The pulse was counted for thirty-second periods, the respirations for one-minute periods. Measurements of arterial blood pressure were made by the auscultatory method with a mercury manometer and a standard arm cuff. A small calibrated spirometer was utilized to measure vital capacity. The effect of intravenous injections on the plasma and blood volume were studied as described in a previous communication (1). The values for blood volume changes reported here were obtained by calculation from the serum protein, hematocrit and estimated control blood volumes before injection, and the protein and hematocrit values after injection (Method $A$ of our previous paper (1)). Electrocardiographic tracings were taken with a Hindle string galvanometer. The above measurements were made at frequent intervals during and after the injection of fluids; in instances where the changes were not great only the changes from the control level to the level at the end of injection are tabulated.

In analyzing the results obtained in this study, changes of less than the following magnitudes were considered insignificant-venous pressure, $2 \mathrm{~cm}$. water; pulse rate, 6 beats per minute; systolic and diastolic blood pressure, $4 \mathrm{~mm}$. $\mathrm{Hg}$; pulse pressure, $4 \mathrm{~mm}$. $\mathrm{Hg}$; velocity of blood flow, 10 per cent. By the method utilized, the volume of 
fluid delivered intravenously was measurable to within approximately $50 \mathrm{cc}$.

In twenty-three studies a total of 500 to $1500 \mathrm{cc}$. of 5 per cent solution of glucose in physiological saline was administered; nine subjects received 1000 to $1500 \mathrm{cc}$. of physiological saline solution; two received 1000 to 1500 cc. of 5 per cent glucose in distilled water; one received $500 \mathrm{cc}$. of a 3 per cent solution of saline.

In most of the experiments venous pressures were measured, decholin was injected for measurements of pulmonary circulation time, and blood was drawn for hematocrit and protein measurements by means of a threeway stopcock connected with the needle inserted in the arm vein utilized for delivery of the fluid. When measurements were made before the total volume of fluid had been injected, the flow of fluid was stopped completely for two to three minutes for duplicate measurements of venous pressure and a single velocity measurement, after which fluid injection was resumed. In some experiments the fluid was delivered in one arm and the antecubital vein of the other arm was utilized for the above measurements. Blood pressure readings during injection were obtained in those experiments where the vein of only one arm was punctured. In calculating the average rate of injection for a given volume of fluid, the total time elapsed between the beginning of injection and the end of injection of that volume, including in many instances one or two brief interruptions for venous pressure or velocity measurements or blood sampling, was utilized.

\section{RESULTS}

\section{Pulse rate}

Significant changes in pulse rate occurred in 14 of 33 studies (Table I). In eleven patients rises of from 6 to 18 beats per minute were found; in two others decreases of 6 beats per minute were observed. The largest increases occurred in subjects receiving a liter or more of fluid; patients receiving hypertonic solutions exhibited a greater tendency toward acceleration of pulse than those receiving isotonic solutions. Measurements of pulse rate made one-half hour after the end of the infusion in patients in whom rises occurred during injection revealed a tendency of the pulse rate to remain somewhat increased for this period.

\section{Arterial blood pressure}

Measurements of arterial blood pressure were made during thirty experiments (Table I).

Significant increases in systolic blood pressure occurred in fifteen patients; in two cases the systolic pressure decreased.
TABLE I

Changes in cardiovascular dynamics following the intravenous administration of fluids

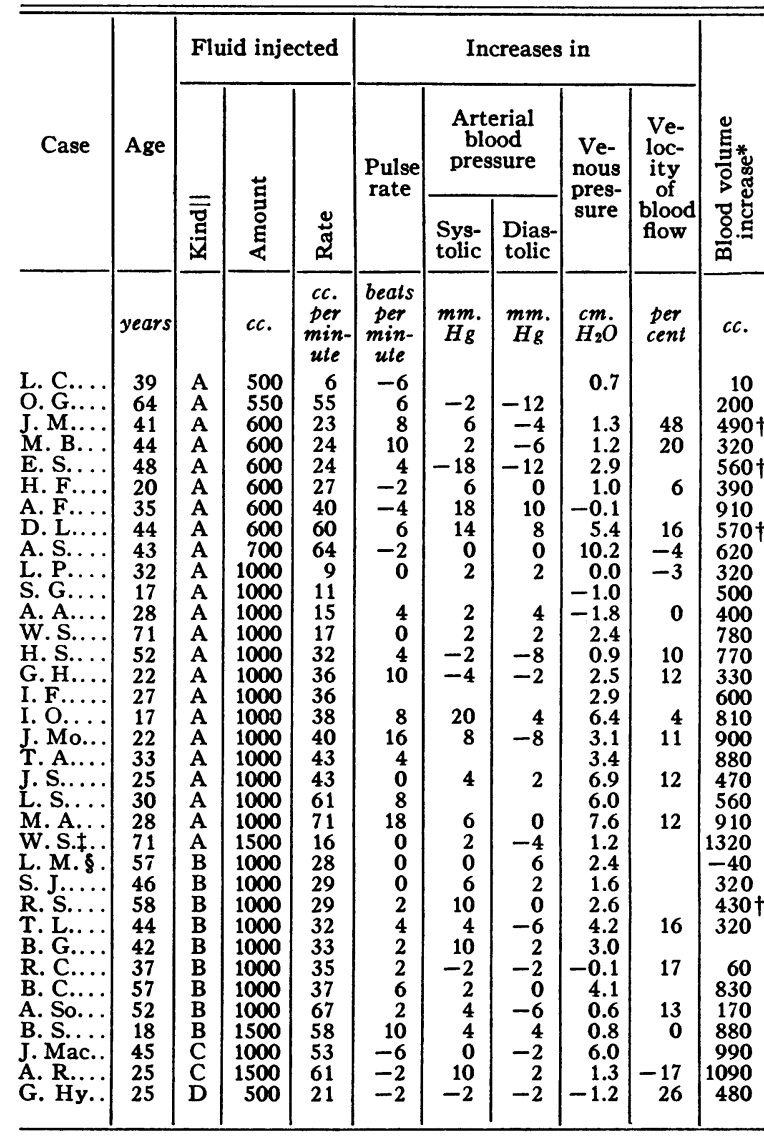

* Changes in blood volume have been calculated from the estimated control blood volume, the hematocrit and plasma protein findings before injection, and the hematocrit and protein values immediately after the injection of fluids according to Method A of our previous paper (1).

$\dagger$ These figures represent plasma volume increases.

$¥$ This study was made two days after the preceding one in this case.

\& Uremia.

II $A=5$ per cent glucose in 0.85 per cent saline.

$\mathrm{B}=0.85$ per cent saline.

$\mathrm{C}=5$ per cent glucose.

$\mathrm{D}=3$ per cent saline.

Fifteen patients exhibited changes in diastolic blood pressure, six showing a rise and nine a fall.

The pulse pressure increased significantly in seventeen instances, decreased in two, and was unchanged in the remaining eleven cases studied. Measurements of blood pressure made one-half hour after the end of injection in those patients whose pulse pressure showed an increase during the period of injection, revealed a tendency of the pulse pressure to remain increased for this period. 


\section{Venous pressure}

The venous pressure was normal before injection of fluid in every subject. During the injection of fluid at a given rate the venous pressure increased as the amount of fluid introduced increased, so that the change after the introduction of $1000 \mathrm{cc}$. was on the average approximately twice as much as after the introduction of 500 cc. (Figure 2).

Analysis of changes at the end of injection of 500 to $600 \mathrm{cc}$. of fluid in thirty-two experiments showed greater increases in venous pressure at faster rates of injection (Figure 1). In 17 of these studies the rate of injection was below 40 cc. per minute; the changes in venous pressure were not appreciable with three exceptions (Figure 1). On the other hand seven of the fifteen cases receiving fluids at rates of $40 \mathrm{cc}$. per minute or greater showed increases of venous pressure

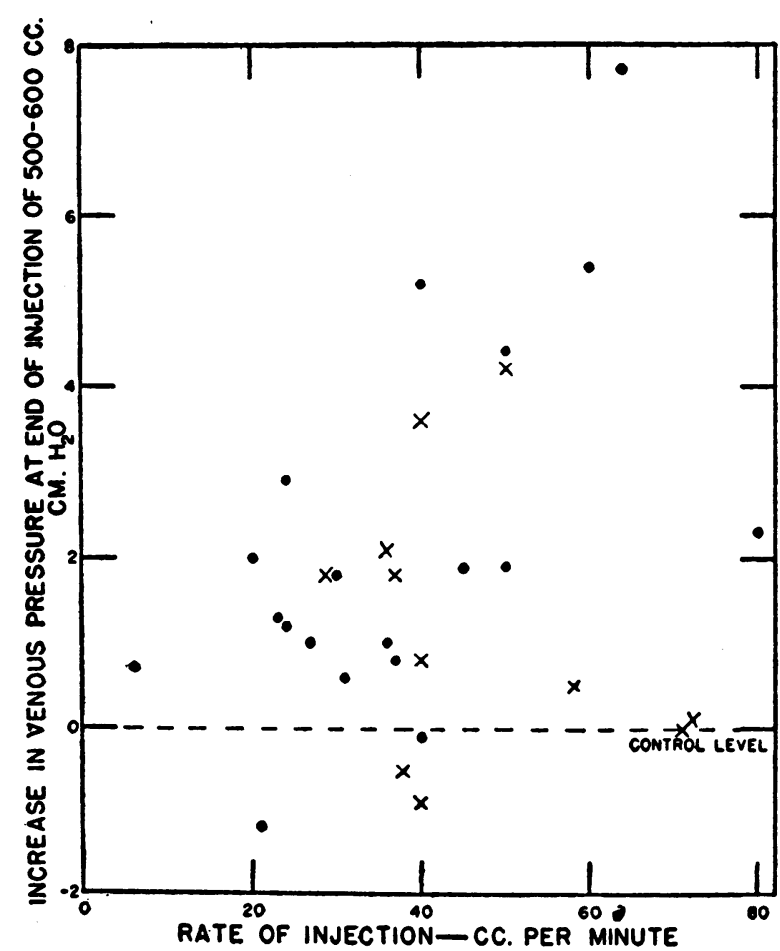

Fig. 1. Relationship between Increase in Venous Pressure and Rate of Injection of Fluid Intravenously; the Volume Administered Was 500 to $600 \mathrm{cc}$.

Dots represent cases receiving 5 per cent glucose in physiological saline solution; crosses represent cases receiving physiological saline solution or 5 per cent glucose solution in distilled water.

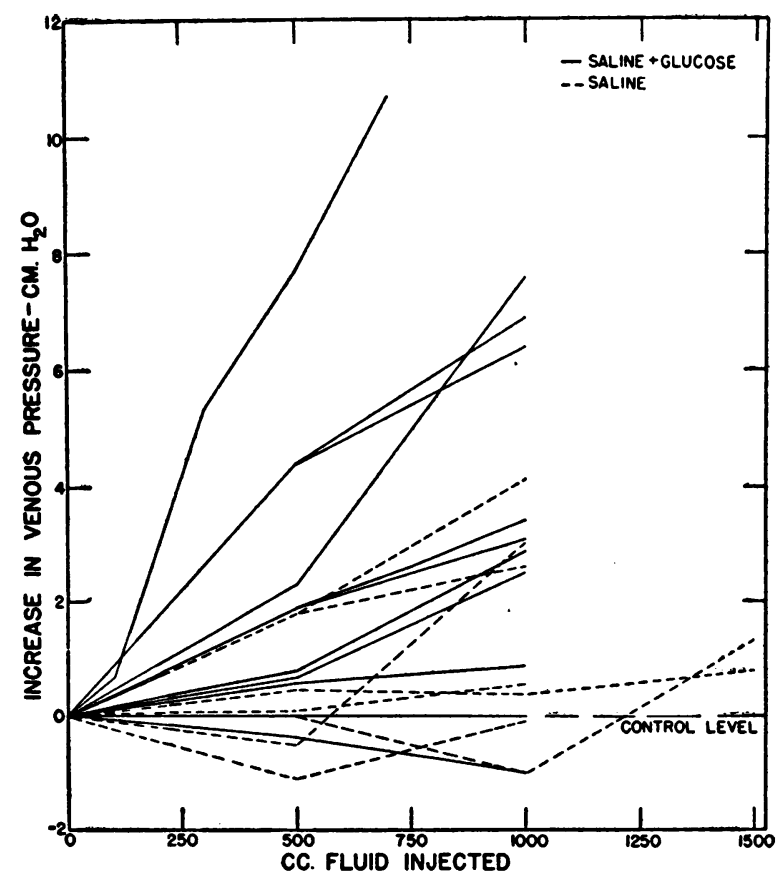

Fig. 2. Relationship between Increase in Venous Pressure and Amount of Fluid Injected

Solid lines represent cases receiving 5 per cent glucose in physiological saline solution; broken lines represent cases receiving physiological saline solution or 5 per cent glucose solution in distilled water.

of 2.3 to $7.7 \mathrm{~cm}$. of water after 500 to $600 \mathrm{cc}$. were injected.

In several instances in which $1000 \mathrm{cc}$. of fluid were injected the venous pressure increased to values above $12 \mathrm{~cm}$. of water during the administration of fluid; in one subject a venous pressure of $19.2 \mathrm{~cm}$. of water was obtained at the end of injection of $700 \mathrm{cc}$. of fluid at a rate of $64 \mathrm{cc}$. per minute.

The rise in venous pressure resulting from the intravenous administration of fluid depended to a considerable degree upon the nature of the fluid injected. For a given volume and rate of injection the venous pressure showed a tendency to increase more after hypertonic solutions ( 5 per cent glucose in 0.85 per cent saline) than after isotonic solutions (Table I, Figures 1 and 2).

After cessation of injection the venous pressure, if increased, started immediately to return toward the level obtaining before injection; even in the instances where the venous pressure increased considerably, the values approximated the 


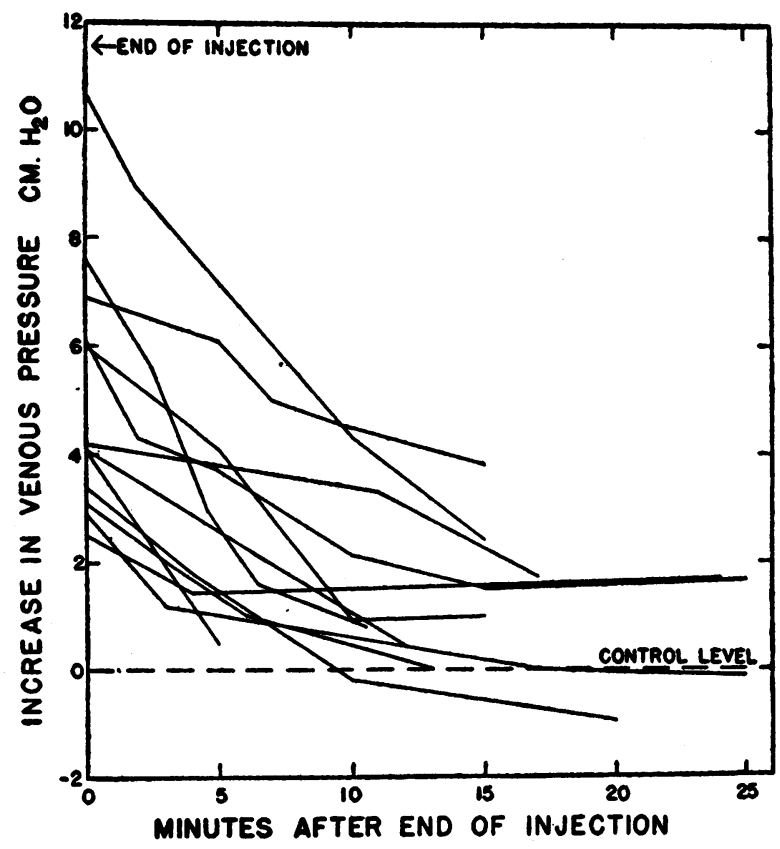

Fig. 3. Rate of Fall of Venous Pressure toward Control Level after Termination of Injection of Fluids Intravenously

Only those cases showing increases in venous pressure of $2 \mathrm{~cm}$. or more at the end of injection are represented.

control figures in 10 to 25 minutes after the end of injection (Figure 3).

\section{Velocity of blood flow}

The arm to tongue circulation time was measured in 15 patients after 500 to $600 \mathrm{cc}$. of fluid had been given intravenously. Significant increases in velocity occurred in 10 instances; in 5 instances the increases were 20 per cent or more (Figure 4). The greatest increases in velocity were observed in cases in which the fluid was administered at rates of injection of 20 to $45 \mathrm{cc}$. per minute (Figure 5).

A rough inverse relationship between rise in venous pressure and increase in velocity of blood flow through the lungs was found (Figure 4). Thus, four of nine patients who showed no appreciable increases in venous pressure after 500 to $600 \mathrm{cc}$. of fluid had been injected showed increases in blood velocity of 20 per cent or more; on the other hand only one of six patients who did show appreciable increases in venous pressure exhibited an increase in velocity of blood flow of this magnitude (Figure 4).
Of fifteen patients whose velocity of blood flow was measured more than once during the course of injection, six showed a slower velocity of blood flow after receiving 1000 or $1500 \mathrm{cc}$. of fluid than after receiving 500 or $1000 \mathrm{cc}$. (Figure 5). In most of the other nine patients the maximum rate of increase in velocity of blood flow was observed during the injection of the first $500 \mathrm{cc}$. of fluid, the curve of velocity increase against amount of fluid injected falling off as more fluid was injected (Figure 5).

\section{Cardiac output}

The effect of the intravenous injection of 400 to $1000 \mathrm{cc}$. of fluid on the cardiac minute volume output was measured in six patients (Table II). The rate of injection of fluid in these cases varied from 11 to $36 \mathrm{cc}$. per minute. In three patients who showed no rise in venous pressure during the intravenous infusion the average increase in cardiac output per $100 \mathrm{cc}$. of oxygen consumption was 10 per cent (Table II). The average increase in cardiac output in the three patients in whom rises in venous pressure occurred was approximately 40 per cent. The increases in venous pressure noted in these subjects was small (Table II). The increases in cardiac output in these

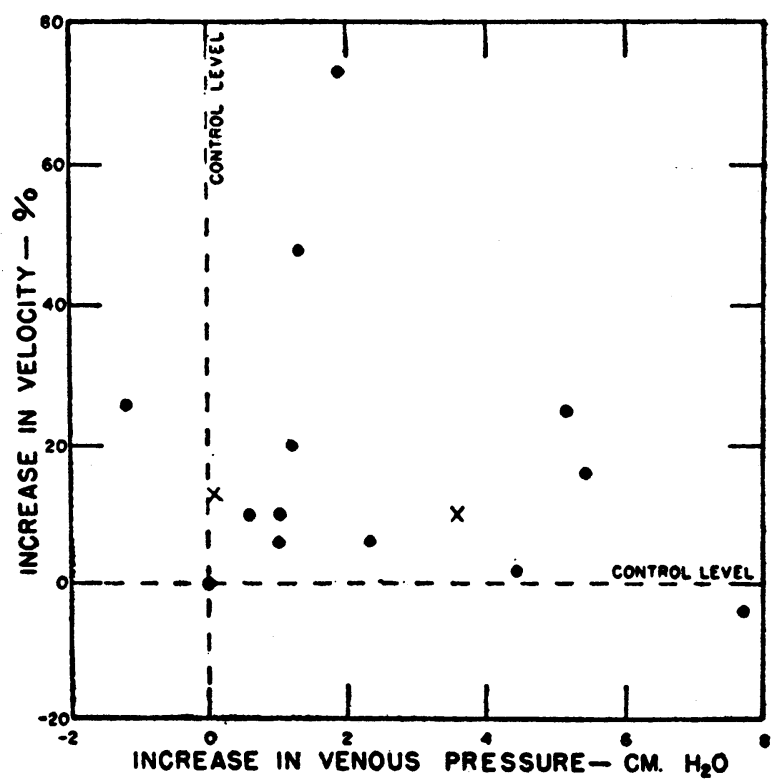

Fig. 4. Reinationship between Changes in Vhocity of Blood Flow and in Venous Pressure after INJection of 500 to $600 \mathrm{cc}$. OF Fluid Intravenously 


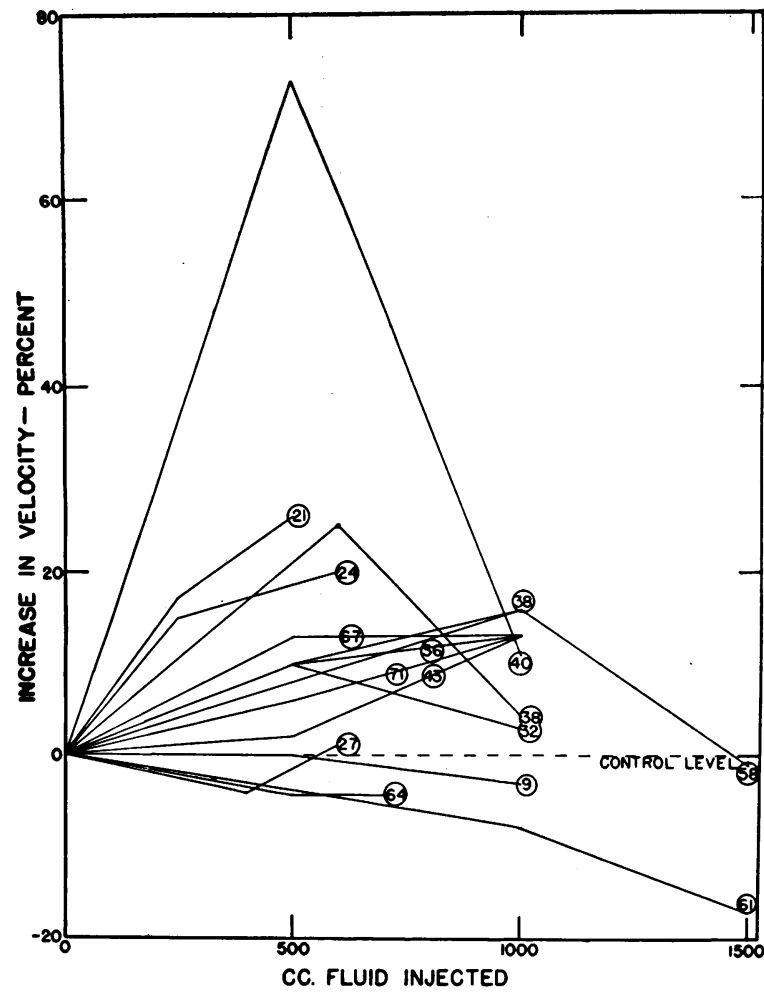

Fig. 5. Relationship between Increase in Velocity of Blood Flow and Volume of Fluid Injected in Subjects in Whom Repeated Measurements Were Made at Various InTERVALS DURING InJection

The figures in circles indicate the rate of injection.

studies resulted entirely from increases in volume output per beat, since the pulse rates remained unchanged.

The velocity of blood flow was measured in three of the patients in whom cardiac output studies were made. In one instance, the increase in velocity was proportional to the rise in cardiac output; in the other two cases in which the fluids were administered at more rapid rates, the per cent increase in velocity of blood flow was markedly less than the per cent increase in cardiac output.

The arteriovenous oxygen difference was strikingly diminished in the patients in whom the largest increases in cardiac output occurred; lesser decreases were found in the other cases.

\section{Respiratory dynamics}

The respiratory rate increased by more than two respirations per minute in only two of twentysix studies.
TABLE II

Changes in cardiac output and related aspects of the circulation during the injection of fluids intravenously

\begin{tabular}{|c|c|c|c|c|c|c|c|c|c|c|c|c|}
\hline \multirow{2}{*}{ Case } & \multicolumn{3}{|c|}{$\begin{array}{l}\text { Cardiac output } \\
\text { per } 100 \text { cc. } \\
\text { oxygen } \\
\text { consumed }\end{array}$} & \multicolumn{2}{|c|}{$\begin{array}{l}\text { Pulse } \\
\text { rate }\end{array}$} & \multicolumn{2}{|c|}{$\begin{array}{l}\text { Arteriove- } \\
\text { nous oxy- } \\
\text { gen dif- } \\
\text { ference }\end{array}$} & \multirow{2}{*}{ 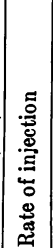 } & \multirow{2}{*}{ 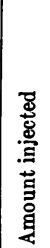 } & \multirow{2}{*}{ 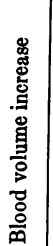 } & \multirow{2}{*}{ 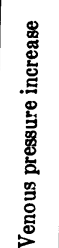 } & \multirow{2}{*}{ 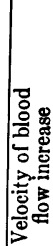 } \\
\hline & $\begin{array}{c}\text { Be- } \\
\text { fore } \\
\text { in- } \\
\text { jec- } \\
\text { tion }\end{array}$ & $\begin{array}{l}\text { Dur- } \\
\text { ing } \\
\text { in- } \\
\text { jec- } \\
\text { tion }\end{array}$ & $\begin{array}{c}\text { In- } \\
\text { crease }\end{array}$ & $\begin{array}{c}\text { Be- } \\
\text { fore } \\
\text { in- } \\
\text { jec- } \\
\text { tion }\end{array}$ & $\begin{array}{l}\text { Dur- } \\
\text { ing } \\
\text { in- } \\
\text { jec- } \\
\text { tion }\end{array}$ & $\begin{array}{c}\text { Be- } \\
\text { fore } \\
\text { in- } \\
\text { jec- } \\
\text { tion }\end{array}$ & $\begin{array}{l}\text { Dur- } \\
\text { ing } \\
\text { in- } \\
\text { jec- } \\
\text { tion }\end{array}$ & & & & & \\
\hline & liters & liters & $\begin{array}{c}\text { per } \\
\text { cent }\end{array}$ & $\begin{array}{c}\text { beats } \\
\text { per } \\
\text { min- } \\
\text { ute }\end{array}$ & $\begin{array}{c}\text { beats } \\
\text { per } \\
\text { min- } \\
\text { ute }\end{array}$ & $\begin{array}{l}\text { tol- } \\
\text { umes } \\
\text { per } \\
\text { cent }\end{array}$ & $\begin{array}{c}\text { vol- } \\
\text { umes } \\
\text { per } \\
\text { cent }\end{array}$ & $\begin{array}{c}\text { cc. } \\
\text { per } \\
\text { min- } \\
\text { ute }\end{array}$ & $c c$. & $c c$. & $\stackrel{\mathrm{cm}}{\mathrm{H}}$. & $\begin{array}{l}\text { per } \\
\text { cent }\end{array}$ \\
\hline $\begin{array}{l}\text { S. G.... } \\
\text { G. Hy.* } \\
\text { A. A... } \\
\text { R. S.... } \\
\text { H. F.... } \\
\text { G. H.... }\end{array}$ & $\begin{array}{l}1.86 \\
1.49 \\
1.52 \\
1.74 \\
1.30 \\
1.34\end{array}$ & $\begin{array}{l}1.86 \\
1.71 \\
1.76 \\
2.18 \\
1.75 \\
2.06\end{array}$ & $\begin{array}{r}0 \\
15 \\
16 \\
25 \\
35 \\
54\end{array}$ & $\begin{array}{l}68 \\
75 \\
61 \\
66 \\
78 \\
70\end{array}$ & $\begin{array}{l}66 \\
76 \\
58 \\
68 \\
78 \\
70\end{array}$ & $\begin{array}{l}5.4 \\
6.7 \\
6.6 \\
5.7 \\
7.7 \\
7.5\end{array}$ & $\begin{array}{l}5.4 \\
5.9 \\
5.7 \\
4.6 \\
5.7 \\
4.9\end{array}$ & $\begin{array}{l}11 \\
21 \\
15 \\
20 \\
27 \\
36\end{array}$ & $\begin{array}{r}1000 \\
400 \\
1000 \\
800 \\
600 \\
1000\end{array}$ & $\begin{array}{l}500 \\
400 \dagger \\
400 \\
\\
390 \\
330\end{array}$ & $\begin{array}{l}-1.0 \\
-1.2 \\
-1.8 \\
+3.1 \\
+1.0 \\
+2.5\end{array}$ & $\begin{array}{r}6 \\
12\end{array}$ \\
\hline
\end{tabular}

* The composition of the fluid administered to case G. Hy. was 3 per cent saline; all other cases of this Table received 5 per cent glucose in physiological saline solution.

$\dagger$ The measurement of blood volume in this case showed an increase of $480 \mathrm{cc}$. after the injection of $500 \mathrm{cc}$. of fluid; the value here presented is estimated.

The other measurements of respiratory dynamics showed no consistent change. The respiratory minute volume was measured in six cases. In four cases it increased between 12 and 43 per cent; it was unchanged in the other two. The tidal air was unchanged in three cases, increased 40 per cent in one and decreased 20 per cent in two. The vital capacity, measured in four studies, showed no change.

In no instance did the patient volunteer the information that he was short of breath, nor did direct questioning in several instances reveal the presence of dyspnea.

The oxygen consumption studied in six cases during fluid injection was variable, remaining unchanged in two cases, decreasing 19 per cent in one, and increasing an average of 25 per cent in three cases. Two of the patients in whom increases occurred became obviously restless during the experiment.

\section{Electrocardiogram}

Studies of the electrocardiogram by means of continuous tracings during the injection of fluid were made in ten patients who received 500 to 1000 cc. of fluid at rates of between 23 and 71 cc. per minute. In five instances no changes occurred, in the other five cases slight changes in the $\mathrm{P}$ or $\mathrm{T}$ wave, or in both, were observed. The 


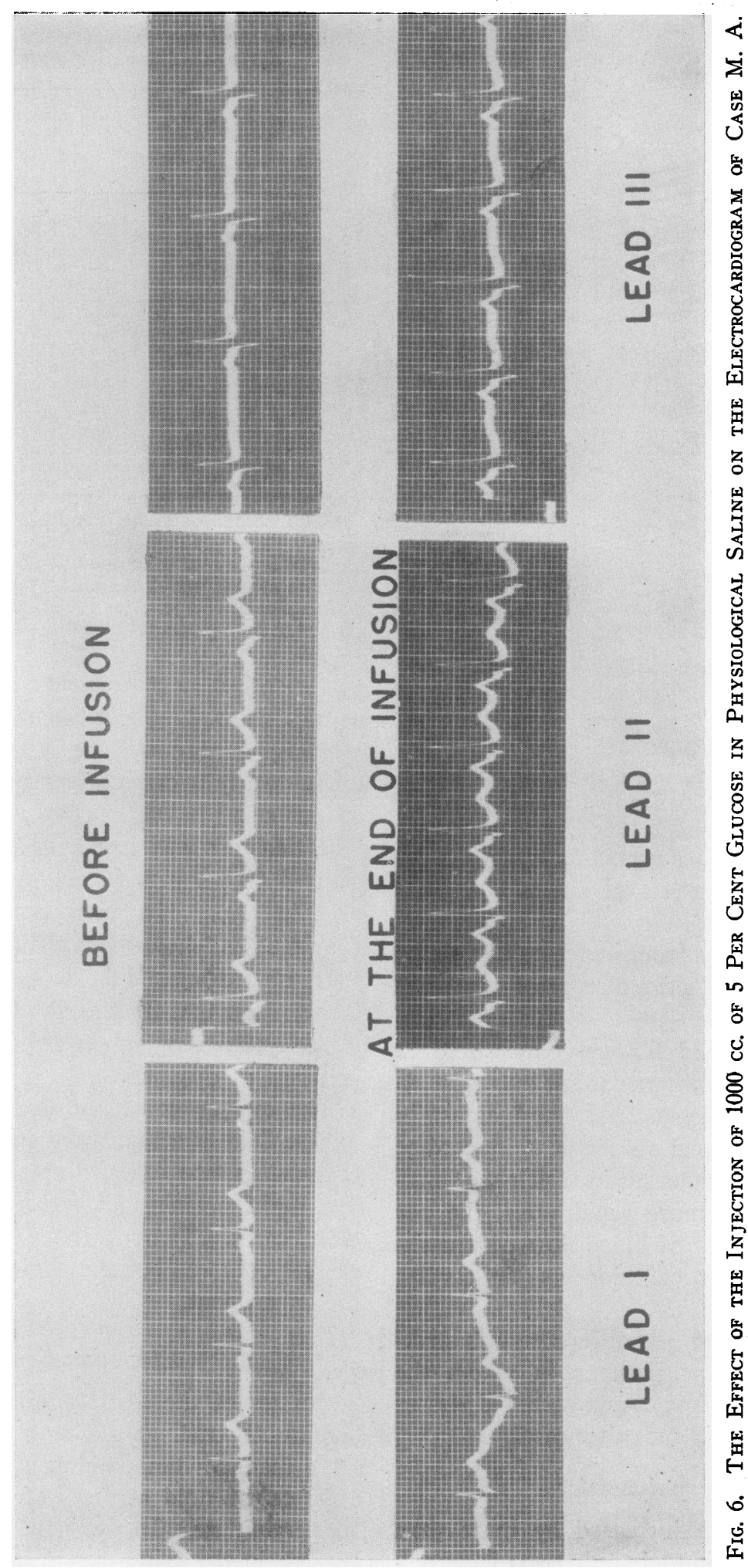


size of the $\mathrm{P}$ wave in one or more leads increased in four instances; in one $\mathrm{P}^{2}$ only was increased, in two others $\mathrm{P}^{2}$ and $\mathrm{P}^{3}$, and in the fourth $\mathrm{P}^{1}$ and $P^{3}$ (Figure 6). Changes in the $T$ wave in one or more leads occurred in four instances, in three of these, changes in $\mathrm{P}$ wave were noted also. In one case $\mathrm{T}^{2}$ was increased, in a second $\mathrm{T}^{1}$ and $\mathrm{T}^{2}$ slightly increased, in a third $\mathrm{T}^{1}$ decreased and in the fourth $\mathrm{T}^{1}$ increased in size while $\mathrm{T}^{2}$ and $\mathrm{T}^{3}$ diminished. Where changes occurred, they were usually first observed when 400 to $700 \mathrm{cc}$. of fluid had been administered.

Four of the five patients whose electrocardiograms showed changes received the injected fluids at rates ranging from 30 to $71 \mathrm{cc}$. per minute. Two of the four patients whose electrocardiographic studies were negative received the fluid at a rate of more than $30 \mathrm{cc}$. per minute.

In two cases where electrocardiographic tracings showed changes during injection, tracings were repeated two to three hours after the end of the injection; at this latter time the tracings were essentially like those before injection.

\section{DISCUSSION}

It has been shown in a previous paper (1) and in Table $I$ above that when fluids are injected intravenously under the conditions of this study a considerable increase in blood volume occurs, and that the blood volume may not return to the control level until two hours after the termination of injection. The observations of the present study describe the various factors concerned in the adaptation of the normal cardiovascular system to the increases in blood volume brought about by fluid injections intravenously.

When volumes of from 500 to $1500 \mathrm{cc}$. of fluid were injected at slow rates (from 6 to $20 \mathrm{cc}$. per minute) there occurred appreciable increases in blood volume, as great as $1300 \mathrm{cc}$. in one case, but very little change in pulse rate, arterial blood pressure, venous pressure, and velocity of blood flow. On the other hand, when fluid was administered at faster rates important changes in many of the cardiovascular measurements were found.

When a liter or more of fluid was injected at rates greater than $20 \mathrm{cc}$. per minute the venous pressure generally became significantly increased. Several investigators have demonstrated in the heart-lung preparation and in the anesthetized, intact animal that increase in venous pressure causes immediate increased output of the heart due to increased filling $(9,11,24,25,26,27)$. In this investigation the cardiac output was measured in three instances in which the venous pressure was increased from 1.0 to $3.1 \mathrm{~cm}$. water by the injection of fluids intravenously. In these experiments the cardiac output increased from 25 to 54 per cent, the increase being accomplished through change in stroke volume. Presumably greater increases in minute volume output may have occurred in those cases showing greater increases in venous pressure. The increased cardiac output found in this study closely accords with the findings in animals of Meek and Eyster (11), Gollwitzer-Meier (12) and Onozaki (14). The results of Gollwitzer-Meier (12) and of Onozaki (14) in dogs and rabbits indicate that the cardiac output decreases to its control level within 15 to 30 minutes after cessation of injection.

The changes in velocity of blood flow during injection of fluids were very variable. At moderate rates of injection the velocity of blood flow usually increased appreciably; with more rapid rates and larger volumes of injection, however, the increase in the velocity of blood flow was considerably less than expected on the basis of the observed changes in cardiac output. The fact that a longer time was consumed by the blood in traversing the pulmonary circuit than that expected with increased cardiac output indicates an increase in the total cross-sectional diameter of the blood stream flowing through the lungs. Stewart (28) has pointed out that the slower the pulmonary circulation time with a given cardiac output, the greater the amount of blood in the lungs. That widely varying volumes of blood may be accommodated in the lungs by virtue of the elasticity of the pulmonary tissue has been suggested by Blumgart and Weiss (29). Evidences of pulmonary engorgement sufficient to cause changes in vital capacity, or respiratory dynamics were not found in our subjects; dyspnea did not occur.

During the course of injection at moderate or more rapid rates the pulse pressure frequently increased progressively and the pulse became bounding. A progressive and diffuse flush was observed in almost all the cases receiving 1000 to 
1500 cc. of fluid. These findings demonstrate peripheral vasodilatation following administration of fluids intravenously. The aforementioned accumulation of fluid in the veins, as indicated by increase in venous pressure, and in the lungs, as indicated by the measurements of velocity of blood flow, when fluid is injected rapidly or in large volume must be regarded as owing to failure of the peripheral vascular bed to dilate sufficiently rapidly to accommodate the increased blood volume. That this lag in peripheral accommodation occasions the increase in venous pressure observed under these conditions is evidenced by the observations that (1) blood volume may be increased more slowly to similar or greater levels without significant rises in venous pressure, and (2) when venous pressure does increase during rapid injections it returns to normal promptly after cessation of injection, although the blood volume remains increased. Peripheral vasodilatation is, therefore, presumably the important factor in the final adaptation of the cardiovascular system to increased blood volume after intravenous infusions.

In general, somewhat greater changes in the blood volume and in the cardiovasular dynamics were observed during injection of the solution containing 5 per cent glucose in physiological saline than when the isotonic solutions, plain physiological saline, or 5 per cent glucose in distilled water, were injected. When solutions more hypertonic than 5 per cent glucose in physiological saline are injected intravenously for therapeutic purposes, the amounts given are usually small in volume. The changes in blood volume and cardiovascular dynamics from such injections would, therefore, not be expected to be as great as many of the changes observed in this study. Gibson and Evans demonstrated an increase in blood volume of approximately 200 cc. during the first few minutes after the intravenous injection of $50 \mathrm{cc}$. of 50 per cent glucose in saline (30).

The findings of elevated venous pressure and evidence of increased pulmonary blood volume in cases of this study are not interpreted as evidences of cardiac insufficiency. The increases in cardiac output when fluids were injected rapidly were much greater than necessary to take up the increased fluid being delivered to the right heart; increases in venous pressure and pulmonary blood volume, therefore, are not attributable to stasis resulting from myocardial insufficiency. Further, a much decreased arteriovenous oxygen difference was found in subjects of this study with increases in venous pressure and in blood volume following intravenous infusions. This is in contrast to the increased arteriovenous oxygen difference and elevated venous pressure resulting from decreased cardiac output in patients with congestive failure.

The finding of an increase in size of the $P$ wave in the electrocardiogram (Figure 6) is interpreted as owing to increased electrical activity of the auricles, indicating increased work (31), probably a result of increased filling. Changes in $T$ wave, though found as frequently as those in $\mathrm{P}$ wave, were too variable in nature and degree to be amenable to interpretation.

The results of this study and the interpretation placed on the findings describe the sequence of changes in cardiovascular dynamics after intravenous infusions of 500 to $1500 \mathrm{cc}$. of crystalloid solutions in normal subjects. As fluids are injected, there occurs a progressive increase in blood volume accompanied by a tendency toward increase in intravascular pressure. Peripheral capillary vasodilatation intervenes, and when the rate of an injection is slow this mechanism accommodates the increased intravascular fluid volume to such an extent that other changes in cardiovascular status are not observable. On the other hand, during the injection of fluids at faster rates, increases in the volume of the arterial, venous, and pulmonary portions of the circulation become manifest. Within a short period following termination of these faster injections the venous pressure decreases in spite of persistent increase in the blood volume, indicating in these instances, also, final accommodation of the increased blood volume through capillary dilatation. In our previous communication, it was shown that the blood volume returns to normal within approximately two hours after intravenous infusions as administered in this study (1). Increases in venous pressure result in increases in cardiac output which persist apparently for a period corresponding with the duration of the increase in venous pressure.

Changes in cardiovascular function resulting from rapid intravenous infusions resemble in many ways the abnormalities in cardiovascular 
dynamics owing to arteriovenous aneurysm. In both conditions, there is delivery of blood in increased volume and under increased pressure to the heart, with a consequent rise in cardiac output (32). The occurrence of myocardial insufficiency resulting from continued increase in the work of the heart in patients with arteriovenous aneurysm is well known.

The occurrence in elderly or cardiac patients of pulmonary edema and of angina pectoris as a result of the administration of fluids intravenously is not rare (33). It is probable that the increased cardiac work resulting from intravenous infusions is the principal cause of the development of these complications in patients with a damaged myocardium. An additional factor favoring the development of pulmonary edema is the increase in the volume of blood in the lungs which occurs during the intravenous ${ }^{-}$administration of large volumes of fluids. In patients with myocardial insufficiency and peripheral vasodilatation (34) associated with increased blood volume (35) rises in venous pressure and increases in the amount of blood in the lungs would presumably occur after smaller or slower intravenous infusions than those which produce these changes in normal subjects (11). Richards et al. (19) elaborating on Caughey's (17) earlier work observed a decrease in vital capacity, slowing of pulmonary circulation time, and onset of dyspnea during rapid intravenous infusions in some cardiac patients. These authors also noted an abnormally great and prolonged rise in venous pressure following the injection of $1500 \mathrm{cc}$. of normal saline at a rate of approximately $50 \mathrm{cc}$. per minute in patients with heart disease.

Intravenous infusions which continue for a period of several days impose conditions favoring the development of edema, both peripheral and pulmonary, even though in such cases the fluid is given at very slow rates. The lowering of the plasma protein level due to plasma dilution, vasodilatation due to increased blood volume, and the tendency toward increased venous pressure, by operating together over a period of days, may result in clinically perceptible edema (36).

The state of the cardiovascular system after the rapid injection of fluid intravenously is quite the opposite of that obtaining in shock. After intravenous injections, there are observed in- creased blood volume, increased peripheral venous pressure, tendency toward increased systolic blood pressure, decreased arteriovenous oxygen difference, flushing of the skin and bounding pulse; in shock, on the other hand, there occur decreased blood volume, collapse of peripheral veins, reduction of systolic blood pressure, increased arteriovenous oxygen difference, pallor and thready pulse.

Certain implications of the foregoing discussion are suggested in regard to therapeutics. When it is necessary to administer fluids intravenously to elderly, debilitated, or cardiac patients, the fluid injected should be isotonic, in small volume, and injected slowly, i.e., at rates under $15 \mathrm{cc}$. per minute. On the other hand, in the treatment of incipient shock when blood transfusion is not immediately available the crystalloid solution to be given intravenously should be hypertonic, in large volume, and injected rapidly, i.e., at rates over 30 cc. per minute.

\section{SUMMARY AND CONCLUSIONS}

1. The effects of the intravenous injection of isotonic and of slightly hypertonic crystalloid solutions on the venous pressure, pulse rate, arterial pressure, cardiac output, velocity of blood flow, respiratory dynamics, electrocardiogram, and blood volume of normal man have been studied.

2. When 500 to $1500 \mathrm{cc}$. of physiological saline, 5 per cent glucose or 5 per cent glucose in physiological saline solutions, were injected at rates of less than $20 \mathrm{cc}$. per minute, very slight changes were observed in the cardiovascular functions studied; the blood volume was usually considerably increased.

3. When these volumes of fluid were injected at more rapid rates considerable increases in venous pressure, cardiac output, velocity of blood flow, and in blood volume were usually observed; increases in pulse rate, pulse pressure, and in the $P$ wave of the electrocardiogram were observed in some instances.

4. The greater venous pressure increases occurred in subjects who received fluids in the larger volumes and at the more rapid rates. The venous pressure invariably returned to the control level within 10 to 25 minutes after the end of fluid administration.

5. Significant increases in cardiac output oc- 
curred in patients in whom the intravenous injection of fluids resulted in rises in venous pressure.

6. When fluids were injected in larger volume and at more rapid rates the increase in velocity of blood flow was considerably less than that expected from changes in the cardiac output. In some instances the increase in velocity of blood flow was greater after the injection of $500 \mathrm{cc}$. of fluid than after 1000 or $1500 \mathrm{cc}$. These findings are interpreted as indicating an increase in pulmonary blood volume during injection. Dyspnea did not occur, and changes in respiratory dynamics were not observed.

7. The fact that rises in venous pressure did not persist, or even did not occur, in spite of increased blood volume, together with the observation of increasing diffuse flush of the skin, point to a progressive peripheral vasodilatation during the course of injection of fluids. Additional evidence in this regard is the tendency toward increased pulse pressure observed in some subjects.

8. The clinical implications of these findings have been discussed.

\section{BIBLIOGRAPHY}

1. Gilligan, D. R., Altschule, M. D., and Volk, M. C., The effects on the cardiovascular system of fluids administered intravenously in man. I. Studies of the amount and duration of changes in blood volume. J. Clin. Invest., 1938, 17, 7.

2. Loewy, A., Blut und Blutkreislauf in einem Falle von Polycythaemia rubra megalosplenica. Berl. klin. Wchnschr., 1909, 46, 1393.

3. Röver, F., Ueber Hyperglobulie. München. med. Wchnschr., 1911, 58, 2791.

4. v. Bergmann, G., and Plesch, J., Ueber Hyperglobulie. München. med. Wchnschr., 1911, 58, 1849.

5. Mohr, J., Zur Klinik der Polyzythämie. München. med. Wchnschr., 1913, 60, 1739.

6. Liljestrand, G., and Stenström, N., Clinical studies on the work of the heart during rest. II. The influence of variations in the haemoglobin content on the blood flow. Acta med. Scandinav., 1925, 63, 130.

7. Ernst, C., Beitrag zur Frage des Kreislaufes bei der Polycythemia vera. Ztschr. f. klin. Med., 1930, 114, 757.

8. Cohnheim, J., and Lichtheim, L., Ueber Hydrämie und hydrämisches Oedem. Virchows Arch. f. path. Anat., 1877, 69, 106.

9. Bayliss, W. M., and Starling, E. H., Observations on venous pressures and their relationship to capillary pressures. J. Physiol., 1894, 16, 159.
10. Bainbridge, F. A., The influence of venous filling upon the rate of the heart. J. Physiol., 1915, 50, 65.

11. Meek, W. J., and Eyster, J. A. E., The effect of plethora and variations in venous pressure on diastolic size and output of the heart. Am. J. Physiol., 1922, 61, 186.

12. Gollwitzer-Meier, K1., Die hämodynamische Wirkung akuter Veränderungen der Blutmenge bei verschiedener Gefässreaktion. Arch. f. d. ges. Physiol., 1928, 218, 586.

13. Warthen, H. J., Massive intravenous injections. An experimental study. Arch. Surg., 1935, 30, 199.

14. Onozaki, N., Studien über die Veränderungen der Kreislaufsdynamik bei intravasalen Flüssigkeitsinfusionen. I. Veränderungen des Minuten- und Schlagvolumens nach intravenöser Infusion von isotonischen Lösungen. Tohoku J. Exper. Med., 1934, 24, 410.

15. Eyster, J. A. E., and Middleton, W. S., Cardiovascular reactions to hemorrhage and transfusion in man. Am. J. Physiol., 1924, 68, 581.

16. Yesko, S. A., Passalacqua, L. A., and Judd, E. S., The effect on the circulation of the injection of 10 per cent glucose and 1 per cent sodium chlorid following operation. S. Clin. North America, 1929, 9, 969.

17. Caughey, J. L., Jr., Effect of rapid infusion on venous pressure: A test of cardiac reserve. Proc. Soc. Exper. Biol. and Med., 1935, 32, 973.

18. Pickering, G. W., The effect of introducing blood from patients with essential hypertension into other human subjects. Clin. Sc., 1936, 2, 185.

19. Richards, D. W., Jr., Caughey, J. L., Cournand, A., and Chamberlain, F. L., Intravenous saline infusion as a clinical test for right-heart and left-heart failure. Tr. A. Am. Physicians, 1937, 52, 250.

20. Feinberg, S. C., The treatment of coronary artery disease by intravenous injections of hypertonic saline solution. Am. J. M. Sc., 1936, 191, 410.

21. Starr, I., Jr., and Gamble, C. J., An improved method for the determination of cardiac output in man by means of ethyl iodide. Am. J. Physiol., 1928, 87, 450.

22. Winternitz, M., Deutsch, J., and Brüll, Z., Eine klinisch brauchbare Bestimmungsmethode der Blutumlaufszeit mittels Decholininjektion. Med. Klin., 1931, 27, 986.

23. Moritz, F., and v. Tabora, D., Uber eine Methode, beim Menschen den Druck in oberflächlichen Venen exakt zu bestimmen. Deutsches Arch. f. klin. Med., 1910, 98, 475.

24. Patterson, S. W., and Starling, E. H., On the mechanical factors which determine the output of the ventricles. J. Physiol., 1914, 48, 357.

25. Patterson, S. W., Piper, H., and Starling, E. H., The regulation of the heart beat. J. Physiol., 1914, 48, 465.

26. Straub, H., Dynamik des Saügetierherzens. Deutsches Arch. f. klin. Med., 1914, 115, 531. 
27. Wiggers, C. J., and Katz, L. N., The contour of the ventricular volume curves under different conditions. Am. J. Physiol., 1922, 58, 439.

28. Stewart, G. N., The pulmonary circulation time, the quantity of blood in the lungs and the output of the heart. Am. J. Physiol., 1921, 58, 20.

29. Blumgart, H. L., and Weiss, S., Clinical studies on the velocity of blood flow. XI. The pulmonary circulation time, the minute volume blood flow through the lungs, and the quantity of blood in the lungs. J. Clin. Invest., 1928, 6, 103.

30. Gibson, J. G., 2d, and Evans, W. A., Jr., Clinical studies of the blood volume. I. Clinical applications of a method employing the azo dye "Evans Blue" and the spectrophotometer. J. Clin. Invest., 1937, 16, 301.
31. Pardee, H. E. B., Clinical Aspects of the Electrocardiogram. Paul B. Hoeber, New York, 1933.

32. Laplace, L. B., Observations on the effect of an arteriovenous fistula on the human circulation. Am. J. M. Sc., 1935, 189, 497.

33. White, P. D., Heart Disease. The Macmillan Co., New York, 1931.

34. Crawford, J. H., Studies on human capillaries. V. Observations in cases of heart disease with regular rhythm. J. Clin. Invest., 1927, 4, 317.

35. Gibson, J. G., 2d, and Evans, W. A., Jr., Clinical studies of the blood volume. III. Changes in blood volume, venous pressure, and blood velocity rate in chronic congestive heart failure. J. Clin. Invest., 1937, 16, 851.

36. Jones, C. M., and Eaton, F. B., Postoperative nutritional edema. Arch. Surg., 1933, 27, 159. 